\title{
Model Tests on Y-Shaped Piles under Compressive and Lateral Loading in Saturated Sand
}

\author{
Lian-wei Ren $\mathbb{D}^{1},{ }^{1}$ Quan-wei Yang $\mathbb{D}^{2},{ }^{2}$ Gang-qiang Kong $\mathbb{D}^{3}{ }^{3}$ Zhi-lin Dun, ${ }^{1}$ \\ and Xin-yu Wang ${ }^{1}$ \\ ${ }^{1}$ School of Civil Engineering, Henan Polytechnic University, Jiaozuo 454000, China \\ ${ }^{2}$ State Key Laboratory for Geomechanics \& Deep Underground Engineering, China University of Mining and Technology, \\ Xuzhou 221116, China \\ ${ }^{3}$ College of Civil and Transportation Engineering, Hohai University, Nanjing 210098, China
}

Correspondence should be addressed to Lian-wei Ren; renhpu@163.com

Received 8 April 2021; Accepted 13 July 2021; Published 30 July 2021

Academic Editor: José Luis Pastor

Copyright (C) 2021 Lian-wei Ren et al. This is an open access article distributed under the Creative Commons Attribution License, which permits unrestricted use, distribution, and reproduction in any medium, provided the original work is properly cited.

Y-shaped piles are a new type of pile whose cross-section is like the letter Y: they are often used in ground improvement for road or train subgrades in the eastern coastal region of China. To investigate the bearing behaviour of Y-shaped piles in saturated sand, a series of model tests under compressive and horizontal load for Y-shaped piles, $C_{1}$ circular pile (the same cross-sectional area of Y-shaped pile), and $C_{2}$ circular pile (the same perimeter of $\mathrm{Y}$-shaped pile) were carried out. Comparative analysis was conducted on bearing capacity, axial force and side resistance distribution, load sharing ratio, bending moment, and lateral soil pressure distribution along the embedded length. The results show that the bearing capacity of a Y-shaped pile does not increase in proportion, and the shaft resistance is weakened to some extent in saturated sand; Y-shaped pile can effectively improve the compressive bearing capacity for the same amount of concrete. The lateral bearing capacity of a Y-shaped pile has directionality, and hanging a circular section into a Y-shaped section may improve the horizontal bearing capacity for the same amount concrete, but cannot give full play to the advantage of the larger side area for horizontal bearing capacity in saturated sand.

\section{Introduction}

Special-shaped piles often used in engineering are the: H-pile, tapered pile, Closed-Open Ended Pipe piles, belled pile, XCC pile, and Y-shaped pile. These piles have a larger side area for use of less concrete or steel, so are more economical than a circular pile with the same cross-sectional area. An H-pile is usually made of steel and can bear both compressive and horizontal loads [1]. Tapered piles have a varying crosssectional area along their length; the diameter decreases linearly from the pile head. The pile taper should be limited to the top 20-25 pile diameters of the pile length for optimum efficiency [2], and pile-soil radial interaction is thus strengthened and the bearing capacity increased when the taper angle is increased [3]. Belled piles, widely used in Japan, have larger uplift capacity because of the enlarged diameter of pile toe
[4], and the uplift resistance, the soil behaviour around the piles, and the interaction between the soil and the pile surface are investigated for evaluating uplift capacity [5]. The loadcarrying capacity of Closed-Open Ended Pipe piles is affected by different parameters, such as the diameter, the densities of sand soil, whether to add a plug [6], and the saturation of the sand. Rain technology was used to study the influence of different densities on the bearing capacity of different pile diameters [7]; and comparative tests were performed in dry soil and in saturated soil [8], results revealed that the plug does contribute to static pile base capacity and type of piles with closed-open ended type is important, besides low operating frequency ranges, when the soil becomes saturated both the axial strain along with the pile and the amplitude of vibration of the pile head were affected due to the amplification action of the presence of water in soil. A new type of composite pile 


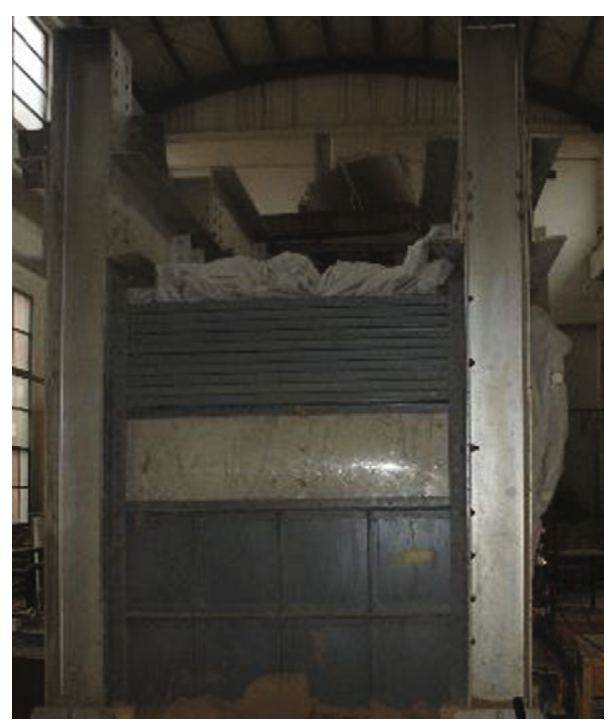

(a)

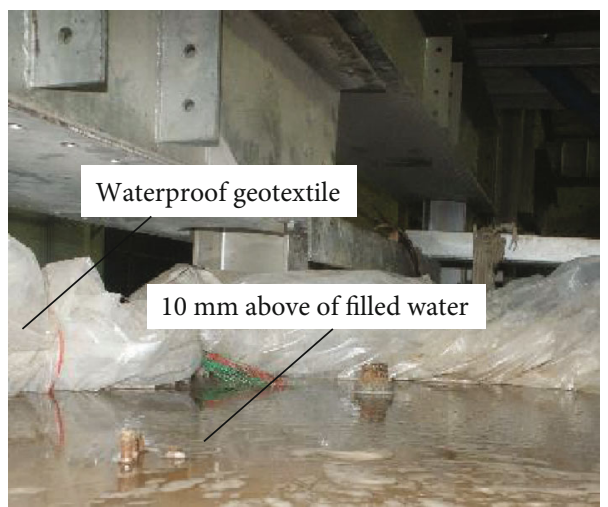

(c)

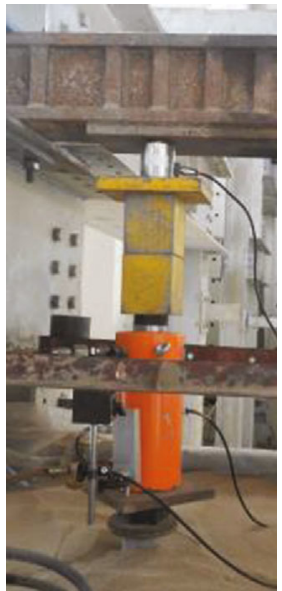

(b) is installed together with jet grouting to form a jet-grout-pilestrengthened pile (JPP) with an expanded cross-section in soft subsoil regions of China to increase bearing capacity and reduce project costs [9].

A new patent of the XCC (X-section cast-in-place concrete pile) pile was developed by Liu and others at Hohai University. Full-scale model tests were carried out to assess the bearing capacity of the XCC pile (Wang et al. 2010 [10]). Combined with ground improvement engineering of the Nanjing sewage treatment plant, field tests to assess load transfer in an XCC pile were carried out (Lv et al. 2011 [11]). [12] investigated the installation effects of XCC piles used in soft clay, the results show that its installation effect is similar to that of a circular pile, and the radius of the XCC pile can be replaced by the radius of a circular pile with the same crosssectional area. Analytical research on installation effects [13] and numerical analysis of load transfer [14] was also carried out for XCC piles in soft clay: the results show that the bearing capacity per amount of concrete of XCC piles exceeds that of a circular pile.

The Y-shaped cast in situ pile with three concave arches was developed [15] and has a larger perimeter than a circular pile with the same cross-sectional area, so its bearing capacity can be improved significantly. This technique has been applied in the soft ground improvement of some highways in Shanghai, Zhejiang, Anhui, and Jiangsu Provinces, China.

Field tests were carried out to analyse the bearing behaviour and treatment effect of Y-shaped piles under highway embankment loading [16], and the load transfer mechanism was analysed based on a reinforcement gauge buried in the Y-shaped pile body in field tests [17] to evaluate the ultimate bearing capacity [18]. The geometric characteristics of a Y-shaped pile were analysed, and comparative analysis between Y-shaped and circular piles was introduced: the theoretical results show that the bearing capacity of a Y-shaped pile is obviously larger than that of a circular pile of the same cross-sectional area [19]. Two types of piled embankment and substratum beneath the SJZA Highway were introduced: tube piles and Y-shaped piles were installed and field test results show that Y-shaped piles used in the embankment are more effective and economical [20]. To facilitate their practical design, eight model tests were conducted in dry sand on Y-shaped piles and circular cross-sectional piles [21]. Horizontal field tests were carried out to analyse the 


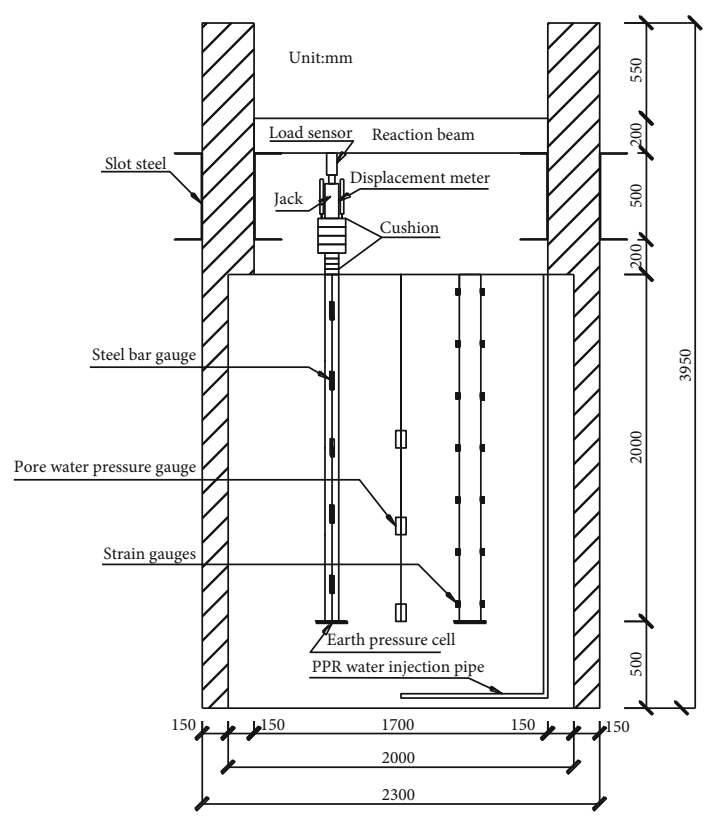

(a)
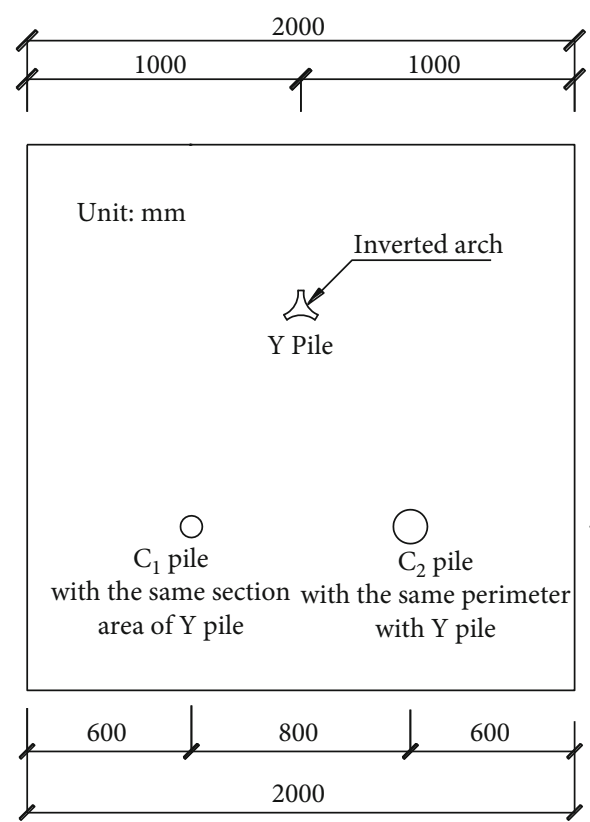

(c)

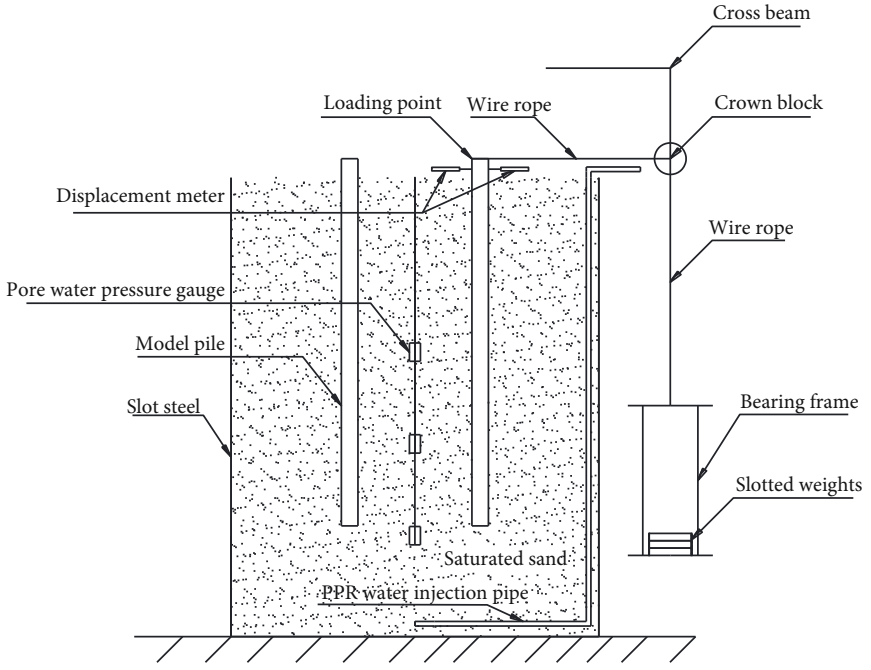

(b)

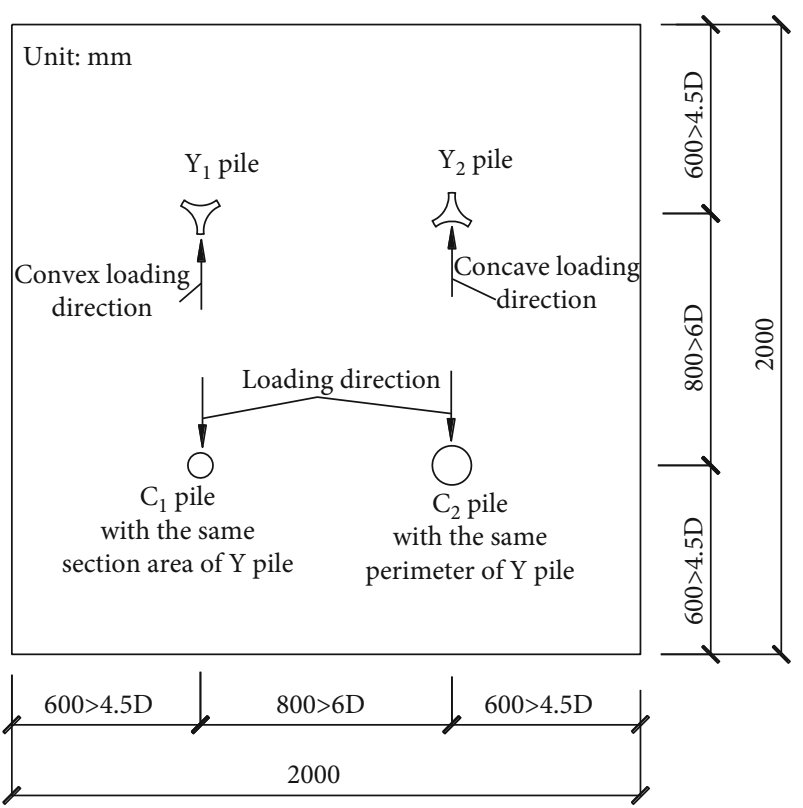

D: the circumcircle diameter of $Y$ pile

(d)

FIGURE 2: Layout of model tests: (a) loading and equipment system under compressive load; (b) loading system under lateral load; (c) crosssectional view of three piles for compressive load tests; (d) cross-sectional view of four piles for lateral load tests.

bearing behaviour of a Y-shaped pile: comparative analysis shows that the horizontal bearing capacity of a Y-shaped pile in a particular load direction is better than that of a circular pile [22]. However, few tests have focused on comparative studies between Y-shaped and circular piles in saturated sand, and research on the horizontal bearing behaviour of Y-shaped piles remains sparse.

Here, we present results of model tests under compressive and horizontal load in saturated sand for a $\mathrm{Y}$-shaped pile, a $C_{1}$ circular pile (having the same cross-sectional area as the Y-shaped pile), and a $C_{2}$ circular pile (having the same perimeter as the Y-shaped pile). Comparative analysis was conducted of the bearing capacity, axial force and side resistance distribution, load sharing ratio, bending moment, and lateral soil pressure distribution along the pile length, and the results provide some suggestions for engineering practice with regard to Y-shaped piles.

\section{Compressive Load Model Tests}

2.1. Model Test System. The model test system is developed and researched independently and consists of a model tank, 


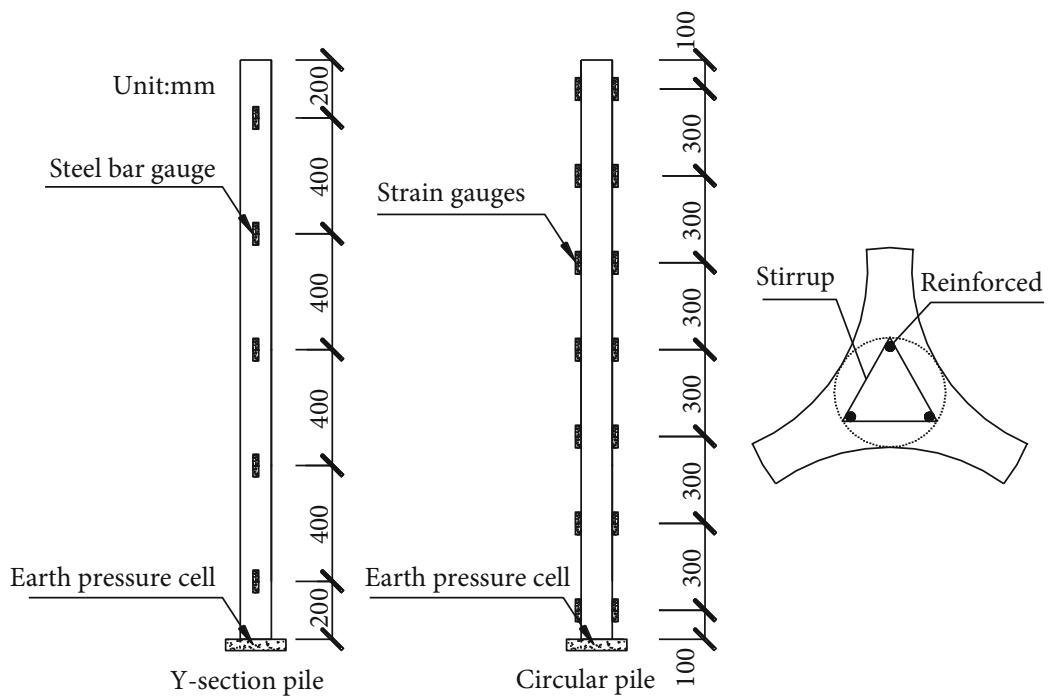

(a)

(b)

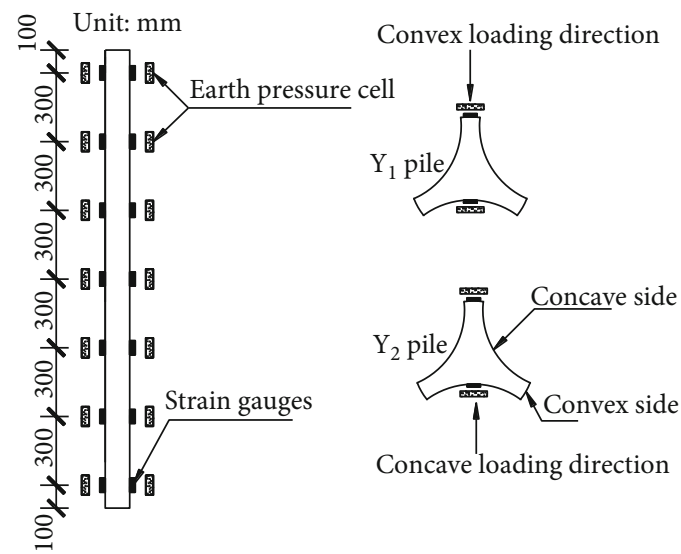

(c)

FIGURE 3: Instrumented model piles: (a) Y-shaped and circular piles under compressive load; (b) steel cage; (c) two Y-shaped piles under convex and concave horizontal loading direction.

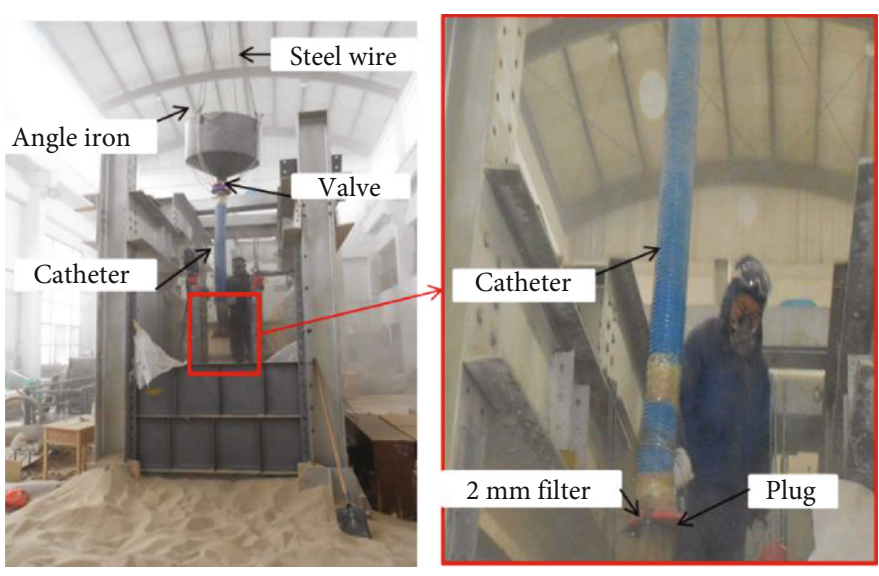

(a)

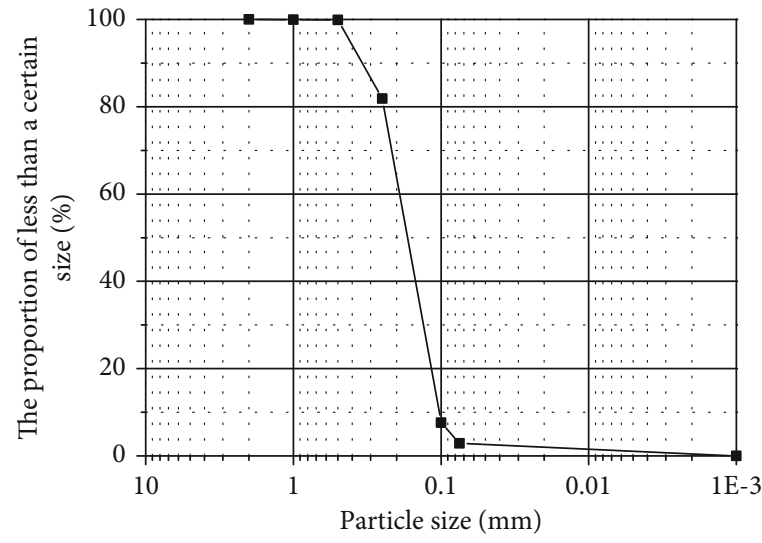

(b)

Figure 4: Sand filling: (a) sand pourer; (b) sand gradation curve.

loading system, and measurement system. The dimensions of the model tank are $2 \mathrm{~m}$ (length), $2 \mathrm{~m}$ (width), and $2.5 \mathrm{~m}$ (height), as shown in Figure 1(a).
The loading system is controlled by a computer and loading occurred automatically, as shown in Figure 1(b), and test data are collected automatically. The tolerance on each 
TABLe 1: Mineralogy of the test sand.

\begin{tabular}{lccccccc}
\hline Mineral composition & Quartz & Feldspar & Metal mineral & Amphibole & Emerald & Garnet & Others \\
\hline Content $(\%)$ & 66.50 & 28.00 & 1.31 & 1.14 & 0.98 & 0.59 & 1.48 \\
\hline
\end{tabular}

applied load is $\pm 0.5 \mathrm{kN}$, so the accuracy and reliability of compressive static load testing are satisfactory.

There are two waterproof layers in the tank: an outer geotextile fabric and inner plastic sheeting (Figures 1(a) and 1(c)). PPR pipe was placed at the bottom of the tank in order to allow water injection. Three pore water pressure gauges are arranged at different depths, and strain gauges are pasted symmetrical on the different positions of Y-shaped pile, as shown in Figures 2(a), 2(b), and 3.

2.2. Test Soil and Construction. The test soil is a fine sand from the Qinhe River near Jiaozuo City, China. Pluviation is used to avoid the uneven impact on relative density [23, 24], as shown in Figure 4(a). The device is designed independently for use as a sand pourer. At first, we filled $50 \mathrm{~cm}$ of dry sand in the bottom of the tank; then locating the model piles, we filled $50 \mathrm{~cm}$ lifts each time until the model piles were buried in pluviated sand. The relative density of dry sand used by the pourer method is about $60 \%$. The result of sand gravel testing is shown in Figure 4(b), so the particle gradation is poor. Tests on dry sand show that the maximum void ratio, the minimum void ratio, and the natural void ratio are $0.855,0.522$, and 0.653 , respectively (GB/T 50123-2019) [25]; the relative density is therefore $60.8 \%$. The mineralogy of test sand is shown in Table 1.

The Y-shaped pile is mainly used in eastern coastal areas of China and is often buried in saturated soil. So first, the model sand is fully saturated: water filling begins after the model piles are buried; filling water slowly into the sand by using the pipe until a water level $10 \mathrm{~mm}$ below ground is established (Figure 1(c)). The whole filling process took about 24 hours. Sand consolidation is natural, $10 \mathrm{~mm}$ water above the sand is drained off after sand consolidation has been substantially completed, and then, the model is covered with plastic sheeting to prevent evaporation. Soil consolidation is deemed complete when the pore water pressure is equal to the hydrostatic pressure and the excess pore water pressure has dissipated. The loading test begins when the sand at different depths has reached the state of normal consolidation. Three pore pressure gauges are installed beforehand at depths of $1.0 \mathrm{~m}, 1.5 \mathrm{~m}$, and $2.0 \mathrm{~m}$, respectively; the pore pressures in saturated sand are $10.12 \mathrm{kPa}, 15.09 \mathrm{kPa}$, and $20.13 \mathrm{kPa}$, respectively. The properties of the consolidated, saturated sand are listed in Table 2.

2.3. Model Piles. The sizes of the Y-shaped piles used in practical engineering are as follows: radius $R=39.6 \mathrm{~cm}$, length $12 \mathrm{~m}$. Each Y-shaped model pile is precast at a similarity ratio of $1: 6$ (radius $R=6.6 \mathrm{~cm}$, length $2 \mathrm{~m}$ ). Two circular piles are also precast: one has the same cross-sectional area as the $\mathrm{Y}$ shaped pile, called $C_{1}$; another has the same perimeter as the Y-shaped pile, called $C_{2}$. The plan arrangement of three
TABLE 2: Properties of consolidated saturated sand.

\begin{tabular}{lccc}
\hline \multirow{2}{*}{ Parameter } & \multirow{2}{*}{ Unit } & \multicolumn{2}{c}{ Value } \\
& & Depth: $20 \mathrm{~cm}$ & Depth: $50 \mathrm{~cm}$ \\
\hline Water content, $w$ & $\%$ & 16.84 & 24.86 \\
Saturated unit weight & $\mathrm{kN} / \mathrm{m}^{3}$ & 18.51 & 18.74 \\
Compressive modulus, $E_{s}$ & $\mathrm{MPa}$ & 12.28 & 13.14 \\
Saturation & $\%$ & 66.3 & 86.1 \\
Specific gravity & - & 2.63 & 2.63 \\
Void ratio & - & 0.673 & 0.665 \\
Relative density & - & 0.548 & 0.570 \\
Cohesion, $c$ & $\mathrm{kPa}$ & 8.89 & 13.03 \\
Friction angle, $\varphi$ & $\circ$ & 38.1 & 38.2 \\
\hline
\end{tabular}

TABle 3: Model pile parameters.

\begin{tabular}{lccc}
\hline Parameter & \multicolumn{3}{c}{ Value } \\
& $Y$ pile & $C_{1}$ pile & $C_{2}$ pile \\
\hline Section area $\left(\mathrm{mm}^{2}\right)$ & 4992.4 & 4992.4 & 12185.6 \\
Section perimeter $(\mathrm{mm})$ & 391.1 & 250.5 & 391.1 \\
Outsourcing radius $(\mathrm{mm})$ & 66 & - & - \\
Arc spacing $(\mathrm{mm})$ & 20 & - & - \\
Arc angle $\left({ }^{\circ}\right)$ & 72 & - & - \\
Radius $(\mathrm{mm})$ & - & 39.9 & 62.3 \\
Length $(\mathrm{m})$ & 2.0 & 2.0 & 2.0 \\
\hline
\end{tabular}

model piles is shown in Figure 2(c). The spacing between piles and the pile and tank wall is over six and four times the circumcircle diameter of the Y-shaped pile, respectively. Pile-pile interaction and boundary effects are minimised in these model tests. Comparative analysis can be undertaken after load testing of the three model piles.

The stiffness of the concrete used in the three model piles is the same with a Young's modulus of $28 \mathrm{GPa}$, the main reinforcement of steel cage is $3 \phi 6$, the stirrups are $\phi 2 @ 20$, and steel cage is placed in the inscribed circle, as shown in Figure 3(b). The parameters of the three model piles are summarised in Table 3.

2.4. Testing Cell Arrangement. Considering the inconvenience of strain gauges pasted on a Y-shaped pile, steel gauges (XHX-306, $\Phi 6 \mathrm{~mm}$, Changsha, China) were bundled on the main reinforcement and, then, cast within the pile (Figure 3(a)). As shown, strain gauges (BX120-50AA, Taizhou, Zhejiang, China) are pasted symmetrically on the circular pile. The strain gauge resistance is $120 \Omega$, and the gate length $\times$ width formed a $50 \times 3(\mathrm{~mm})$ grid . 

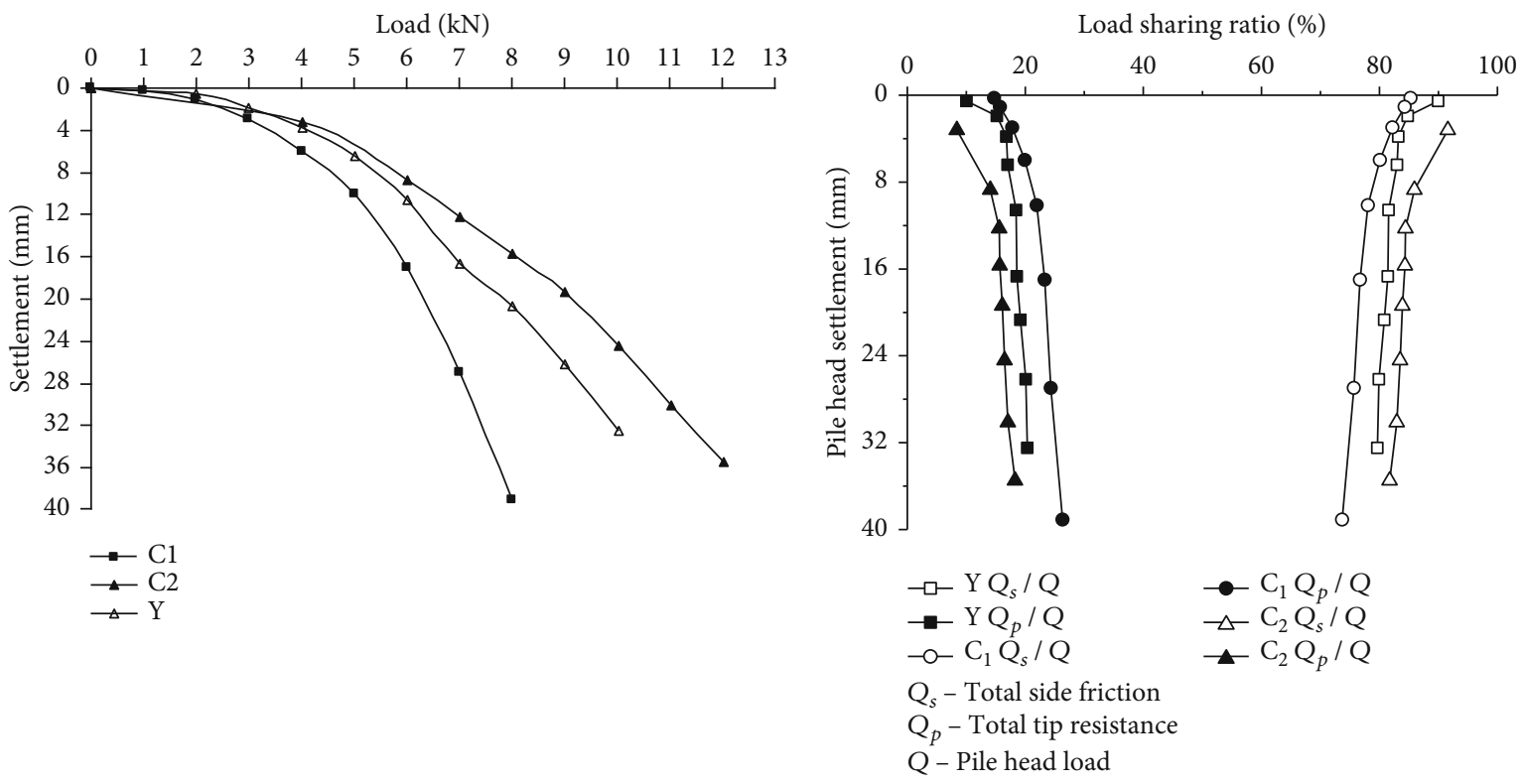

(a)

(b)

FIGURE 5: Model tests under compressive load: (a) pile head load-settlement; (b) load sharing ratio.

TABLE 4: Comparison of compressive loading tests.

\begin{tabular}{lccc}
\hline Items & Value & $C_{1}$ pile & $C_{2}$ pile \\
\hline Ultimate bearing capacity $(\mathrm{kN})$ & 6.20 & 4.80 & 7.00 \\
Bearing capacity ratio to $C_{1}$ pile & 1.29 & 1.00 & 1.46 \\
Concrete amount $\left(\mathrm{cm}^{3}\right)$ & 9984.70 & 9984.70 & 24371.20 \\
Concrete amount ratio to $C_{1}$ pile & 1.00 & 1.00 & 480.74 \\
Bearing capacity per concrete $\left(\mathrm{kN} / \mathrm{m}^{3}\right)$ & 620.95 & 1.00 & 287.22 \\
Bearing capacity per concrete ratio to $C_{1}$ pile & 1.29 & 0.60 \\
\hline
\end{tabular}

An earth pressure gauge is placed at the toe of each model pile (Figure 3(a)), and tip resistance can be measured at each load.

2.5. Loading Procedure. Three axial load tests $\left(Y, C_{1}\right.$, and $\left.C_{2}\right)$ were conducted in accordance with the Chinese Design Code (GB 50007) [26], Quick Load Test Method: the load was applied in increments of $1 \mathrm{kN}$, each load increment was maintained for $5 \mathrm{~min}$, and the load was applied until continuous settlement occurred with no increase in axial load.

\subsection{Test Results and Discussion}

2.6.1. Pile Head Load-Settlement. Figure 5(a) shows the loadsettlement response of three model piles: all such responses are slow; the ultimate bearing capacity of the Y-shaped pile, circular pile $C_{1}$, and circular pile $C_{2}$ are assumed to be $6.2 \mathrm{kN}, 4.8 \mathrm{kN}$, and $7.0 \mathrm{kN}$, respectively. More comparative analysis is summarised in Table 4 .

Figure 5(a) and Table 4 show that

(1) The bearing capacity of the Y-shaped pile is 1.29 times that of the $C_{1}$ pile, while the perimeter of the Y-shaped pile is 1.56 times that of the $C_{1}$ pile
TABLE 5: Main soil properties at test sections in Huangpu highway, China.

\begin{tabular}{|c|c|c|c|c|c|c|}
\hline Layer & $\begin{array}{c}\text { Thickness } \\
(\mathrm{m})\end{array}$ & $\begin{array}{c}\gamma \\
\left(\mathrm{kN} / \mathrm{m}^{3}\right)\end{array}$ & $\begin{array}{c}w \\
(\%)\end{array}$ & $\begin{array}{c}c \\
(\mathrm{kPa})\end{array}$ & $\begin{array}{c}\varphi \\
\text { (degree) }\end{array}$ & $\begin{array}{c}E_{s} \\
(\mathrm{MPa})\end{array}$ \\
\hline Crust & 2.5 & 19.4 & 29.4 & 50.8 & 9.3 & 5.29 \\
\hline $\begin{array}{l}\text { Muddy } \\
\text { clay }\end{array}$ & 5.5 & 180 & 42.3 & 13.0 & 3.2 & 2.97 \\
\hline Silty clay & 6.0 & 19.6 & 28.4 & 54.3 & 10.8 & 6.39 \\
\hline $\begin{array}{l}\text { Sandy } \\
\text { clay }\end{array}$ & 5.0 & 19.4 & 29.2 & 41.6 & 9.5 & 5.55 \\
\hline
\end{tabular}

Notes: $\gamma$ : density; $w$ : water content; $c$ : cohesion by direct shear test; $\varphi$ : friction angle by direct shear test; $E_{s}$ : confined compressive modulus.

although the cross-sectional area of both are the same. The bearing capacity of the Y-shaped pile in saturated sand did not increase in proportion, and the side resistance of the Y-shaped pile was weakened to some extent in saturated sand

(2) The bearing capacity of the $C_{2}$ pile is 1.13 times that of a Y-shaped pile. The cross-sectional area of $C_{2}$ is 


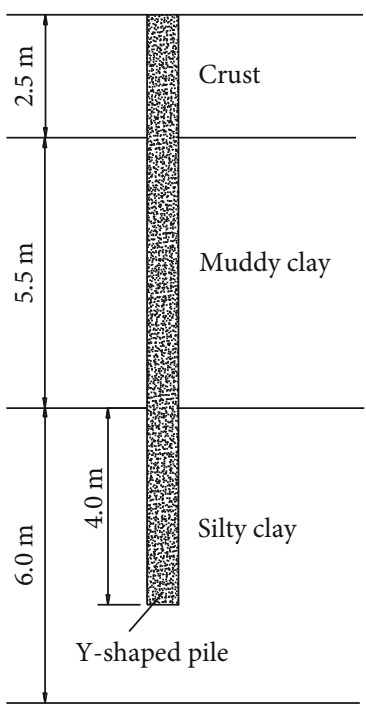

(a)

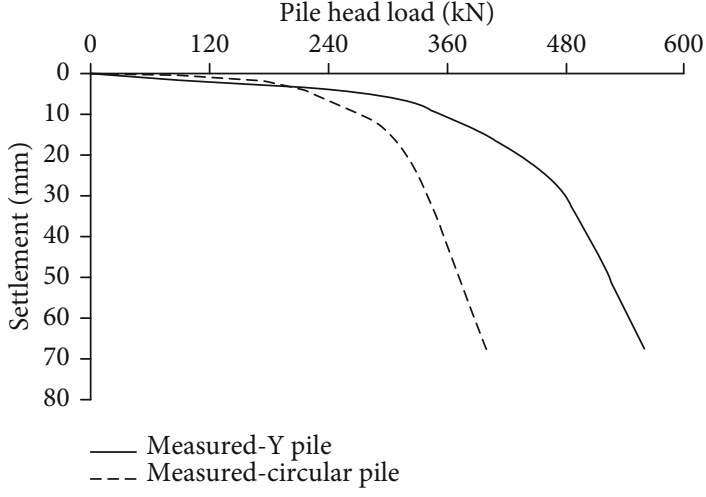

(b)

FIgURE 6: Field case: (a) pile and subsoil profile; (b) field load tests.

larger than that of the Y-shaped pile, so the total tip resistance of $C_{2}$ is larger and the $C_{2}$ pile can achieve a greater bearing capacity although their perimeters are the same. On the other hand, the bearing capacity per unit amount of concrete of the Y-shaped pile is 2.16 times that of the $C_{2}$ pile, so it can be concluded that Y-shaped pile can improve the compressive bearing capacity for the same amount of concrete

2.6.2. Comparisons between Field, and Model Tests. Wang et al. [17] introduced comparative field tests between Yshaped pile and circular pile, which have the same crosssectional area $\left(0.116 \mathrm{~m}^{2}\right)$ and pile length $(12 \mathrm{~m})$, while having perimeters of $1.723 \mathrm{~m}$ and $1.207 \mathrm{~m}$, respectively. The main index and strength properties of the soils under test are listed in Table 5, the groundwater level was at a depth of $-0.5 \mathrm{~m}$, and the pile-soil profile is presented in Figure 6(a). The pile head load-settlement curves are shown in Figure 6(b). Based on Figure 6(b), the ratio of ultimate bearing capacity for a Y-shaped pile and circular pile is $1.38(440 / 320(\mathrm{kN}))$, very close to the ratio of 1.29 found from model testing.

2.6.3. Load Sharing: Side Friction and Tip Resistance. Figure 5(b) shows the load sharing ratio of side friction $\left(Q_{S} / Q\right)$ and tip resistance $\left(Q_{p} / Q\right)$ with pile head settlement. The side friction sharing ratio $\left(Q_{S} / Q\right)$ of the Y-shaped pile is $89.96 \%$ in early-stage loading, and it decreased gradually with increasing load, finally falling to about $80 \%$. The load sharing ratio of the $C_{2}$ pile has a similar distribution to that of the Y-shaped pile, both showing characteristic friction pile behaviour. The load sharing ratio $Q_{S} / Q$ of the $C_{2}$ pile is slightly larger than that of the Y-shaped pile.

Figure 5(b) also shows that the side friction sharing ratio $\left(Q_{S} / Q\right)$ of the $C_{1}$ pile is $85.26 \%$ in early-stage loading, and decreased gradually with increasing load, finally falling to about $70 \%$. The load sharing ratio $Q_{S} / Q$ of a Y-shaped pile is always larger than that of a $C_{1}$ pile.
TABLE 6: Load sharing ratio.

\begin{tabular}{lccccc}
\hline $\begin{array}{l}\text { Pile } \\
\text { type }\end{array}$ & $\begin{array}{c}\text { Bearing } \\
\text { capacity } \\
(\mathrm{kN})\end{array}$ & $\begin{array}{c}\text { Tip } \\
\text { resistance } \\
(\mathrm{kN})\end{array}$ & $\begin{array}{c}\text { Side friction } \\
(\mathrm{kN})\end{array}$ & $\begin{array}{c}Q_{P} / Q \\
(\%)\end{array}$ & $\begin{array}{c}Q_{S} / Q \\
(\%)\end{array}$ \\
\hline$Y$ pile & 6.2 & 1.21 & 4.99 & 19.52 & 80.48 \\
$C_{1}$ & 4.8 & 0.99 & 3.81 & 20.63 & 79.37 \\
pile & & 1.09 & 5.91 & 15.57 & 84.43 \\
$C_{2}$ & 7 & & & & \\
pile & & & & & \\
\hline
\end{tabular}

Circular cross-section piles being changing to Y-shaped sections gain more side friction and improve side friction sharing ratios in saturated sand; however, the side friction sharing ratio of a Y-shaped pile is slightly less than that of a $\mathrm{C}_{2}$ pile, and the side bearing performance is not as good as that of a $C_{2}$ pile despite both having the same crosssectional area.

Load sharing ratios are presented in Table 6 when the pile head load reaches the ultimate bearing capacity. Table 6 shows that $Q_{S} / Q$ of a Y-shaped pile is larger than that of a $C_{1}$ pile, but less than in a $C_{2}$ pile. So Y-shaped sections can improve the side friction ratio but cannot provide the side bearing effect of a circular pile ( $C_{2}$ pile) of the same perimeter.

2.6.4. Axial Force Distribution. Figure 7 shows the axial force distribution for a Y-shaped pile (Figure $7(\mathrm{a})$ ), $C_{1}$ pile (Figure 7(b)), and $C_{2}$ pile (Figure 7(c)). The axial force decreased along each pile under each load with its maximum is at the pile head, the minimum is at the pile toe, and follows the usual general rules.

2.6.5. Side Resistance Distribution. The formula for calculating the side resistance is [21]:

$$
q_{i}=\frac{N_{i}-N_{i+1}}{A_{i}}
$$




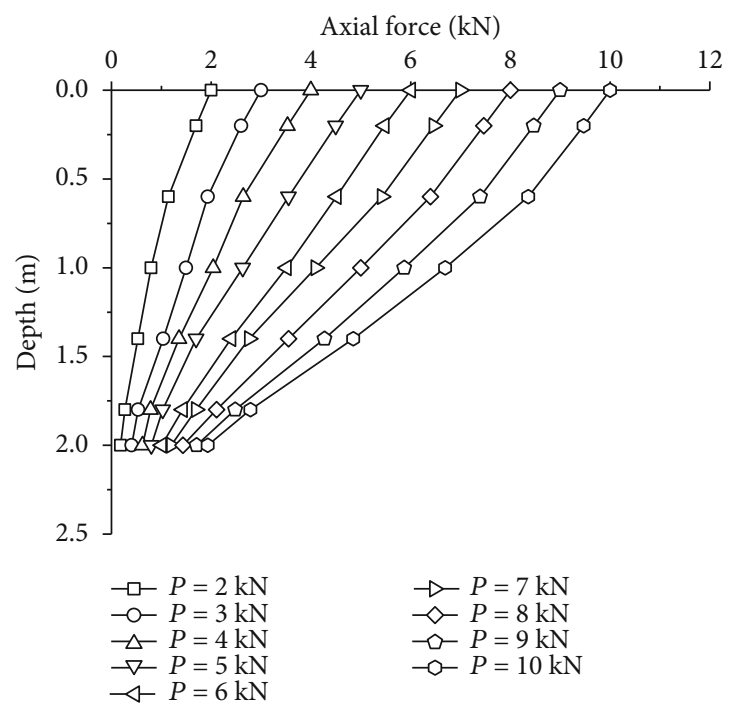

(a)

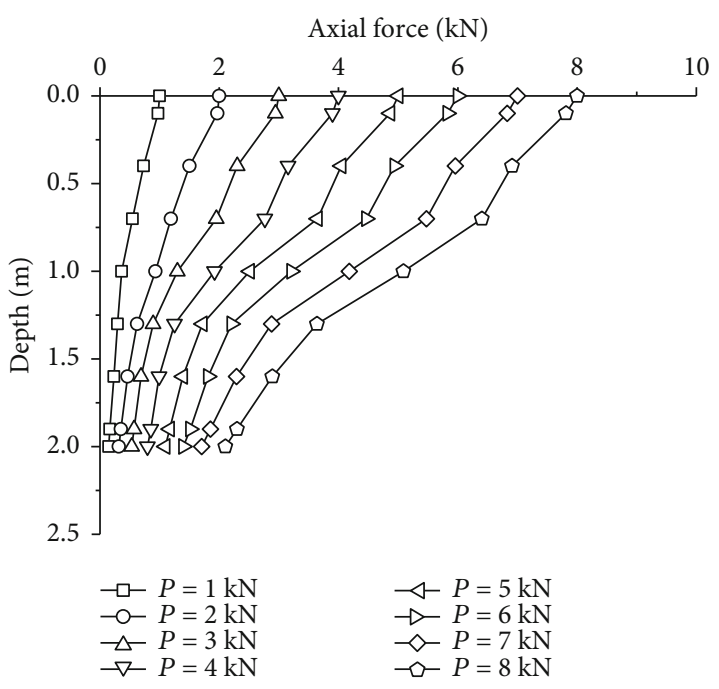

(b)

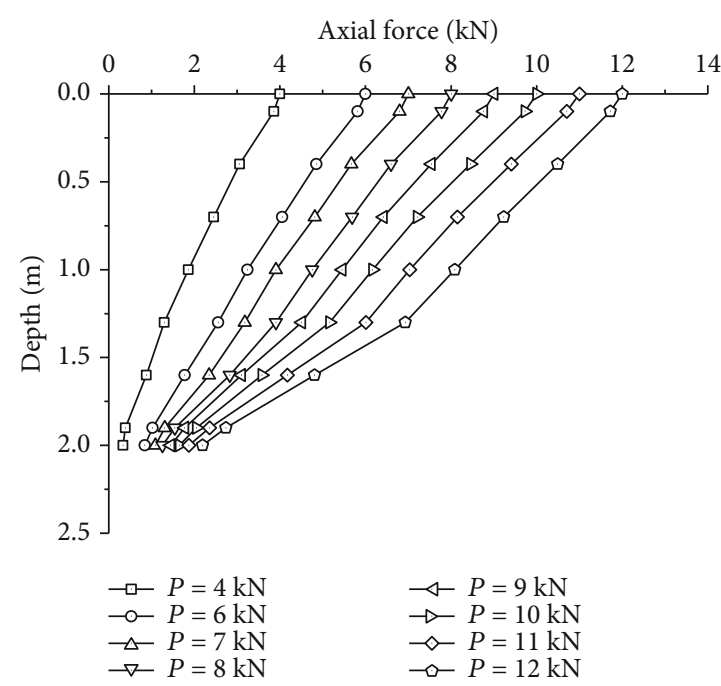

(c)

Figure 7: Axial force distributions along pile depth: (a) $Y$ pile; (b) $C_{1}$ pile; (c) $C_{2}$ pile.

where $q_{i}$ is the average side resistance between section $i$ and section $i+1, N_{i}$ is the axial force on section $i, N_{i}+1$ is the axial force on section $i+1$, and $A_{i}$ is the side area between section $i$ and section $i+1$.

The relationship between the side resistance and the pile depth is presented in Figure 8. Figure 8(a) shows that the side resistance of a Y-shaped pile reaches its peak at around twothirds of the pile length. Figure 8 (b) shows that the side resistance of a $C_{1}$ pile reaches its peak at about half of the pile length and, then, decreases gradually. Figure 8(c) shows that the side resistance of a $C_{2}$ pile reaches its maximum at about four fifths of the pile length.

Figure 8 also shows that the side resistance of a Y-shaped pile is no larger than that of $C_{1}$ and $C_{2}$ circular piles.

\section{Horizontal Load Model Test}

Few studies on the horizontal bearing capacity of Y-shaped pile are presented. Horizontal tests of XCC piles show that their horizontal bearing capacity has directionality and can improve the flexural capacity in a specific direction (Yuan 2009). To investigate the horizontal bearing behaviour of a $\mathrm{Y}$-shaped pile, comparative studies were conducted on the basis of model tests involving Y-shaped and circular piles.

3.1. Plan View of Model Piles. Horizontal load tests of four model piles ( $Y_{1}$ pile, $Y_{2}$ pile, circular pile $C_{1}$, circular pile $C_{2}$ ) were carried out. $Y_{1}$ and $Y_{2}$ piles have the same geometric characteristics in order to research the effects of different loading directions on the horizontal bearing behaviour.

Two Y-shaped piles (similar to those described) were cast: these are the $Y_{1}$ and $Y_{2}$ piles. The horizontal loading direction for these $Y_{1}$ piles and $Y_{2}$ piles is the convex and concave side, respectively, as shown in Figure 2(d). The plan view of the four model piles in the model tank is shown in Figure 2(d). The spacing between piles and pile and tank wall is more than six and 4.5 times the circumcircle diameter of the Y-shaped pile, respectively. 


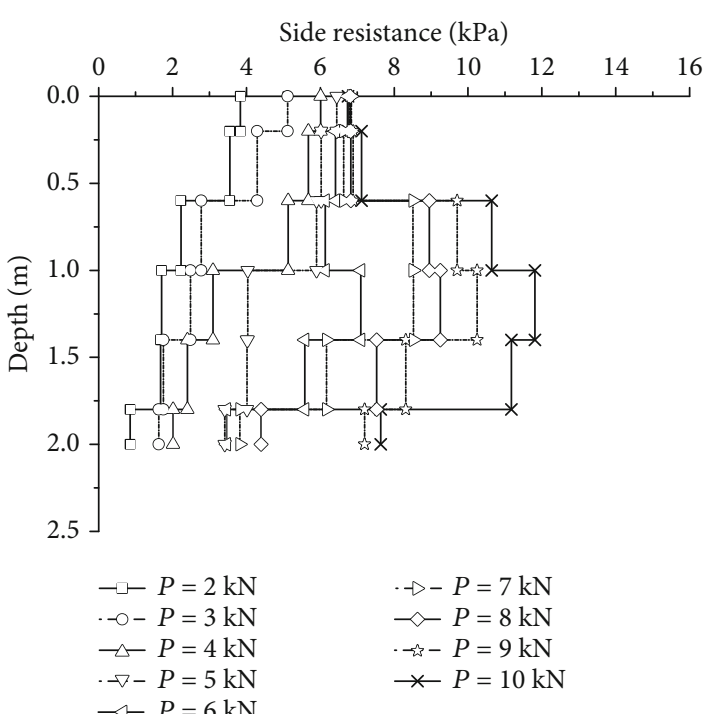

(a)

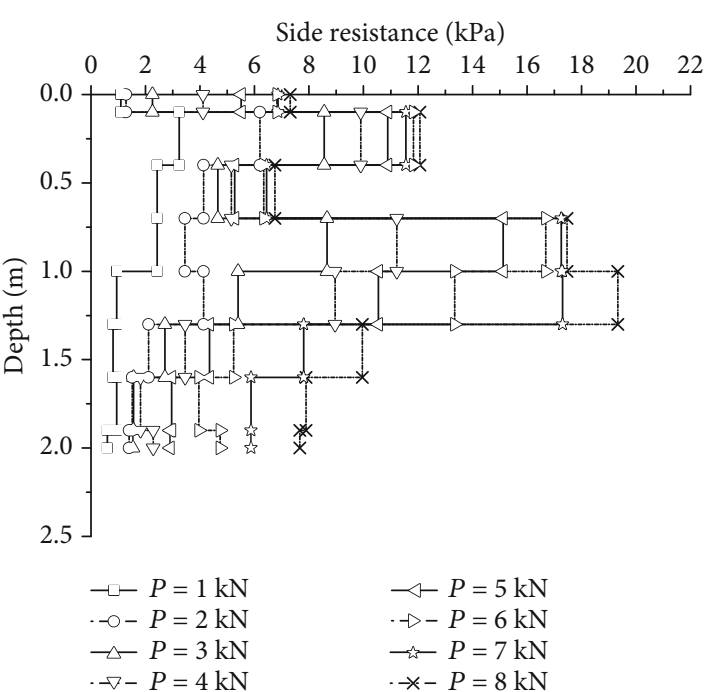

(b)

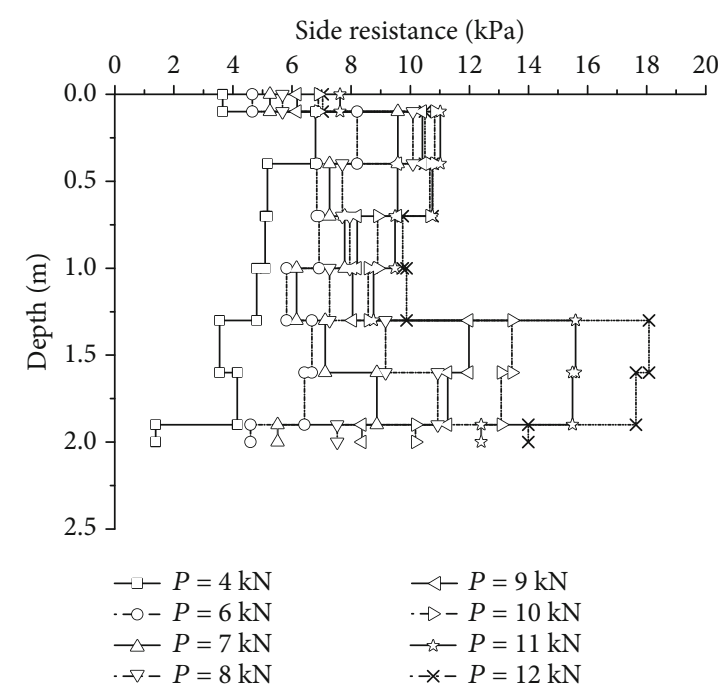

(c)

FIGURE 8: Side resistance distributions along pile depth: (a) $Y$ pile; (b) $C_{1}$ pile; (c) $C_{2}$ pile.

3.2. Horizontal Loading System. Figure 2(b) shows the sketch of the horizontal loading system. The loading device is developed independently based on the characteristics of this tank, using large weights and a pulley to deliver the load.

3.3. Layout of Model Test Equipment. Figure 3(c) shows the position of strain gauges and earth pressure cells. Strain gauges were pasted symmetrically on the model piles, and earth pressure cells were also arranged symmetrically.

3.4. Construction. The construction of the horizontal model test is the same as that used for the compressive test. Four model piles were buried in sand by pluviation, and then, sand was flooded with water and saturated. Model testing began after the saturated sand had been fully consolidated.

3.5. Test Loading Steps. The cyclic lateral load method is used in horizontal model tests, based on the method prescribed in the Chinese Design Code (GB 50007) [26] and described elsewhere $[27,28]$. The loading steps are as follows: apply each load, maintain the load for four minutes, and record the horizontal displacement, then unload to zero, stop for two minutes, and record the residual horizontal displacement; a loading and unloading cycle is thus completed; this load cycle is repeated five times and, then, until continuous lateral displacement occurred with either a slight increase or no increase in load.

\subsection{Test Results and Discussion}

3.6.1. Horizontal Load-Displacement. The horizontal cyclic loads $\left(H_{0}\right)$-displacement curves $\left(X_{0}\right)$ of four model piles are presented in Figure 9. The figure shows that four curves changed slowly. Based on Figure 9, the horizontal load $\left(H_{0}\right)$-displacement gradient $\left(\Delta X_{0} / \Delta H_{0}\right)$ curves of four model piles are presented in Figure 10. Based on Figure 10, 


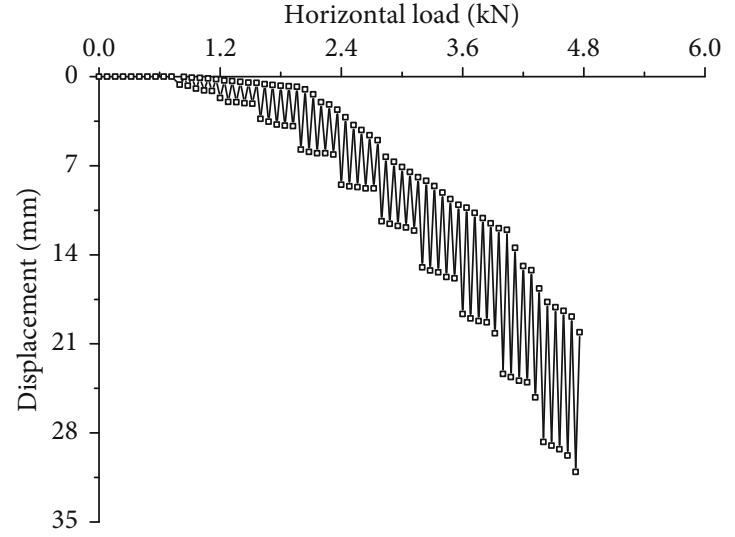

(a)

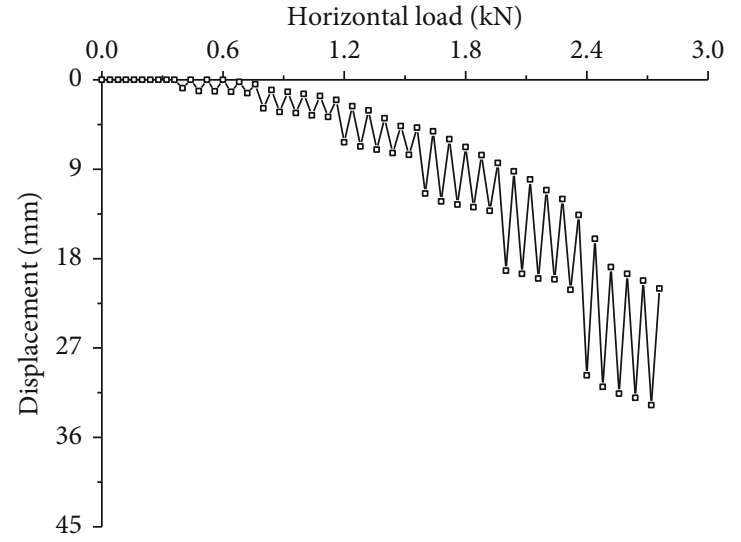

(c)

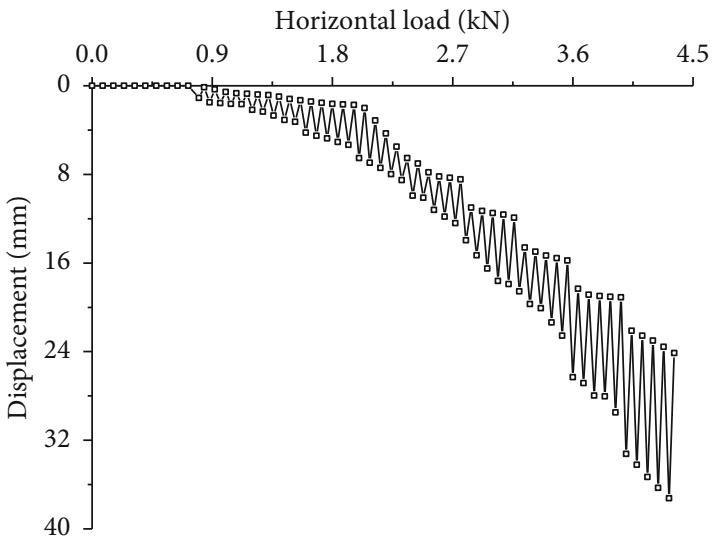

(b)

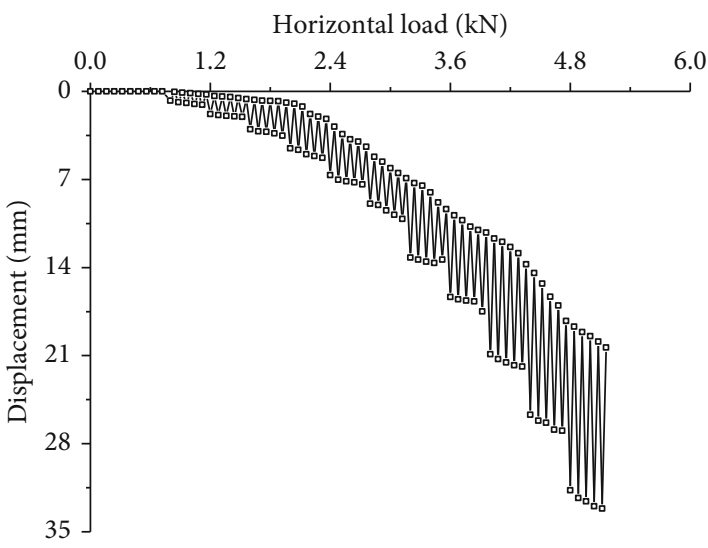

(d)

Figure 9: Horizontal load versus displacement $\left(H_{0}-X_{0}\right)$ : (a) $Y_{1}$ pile; (b) $Y_{2}$ pile; (c) $C_{1}$ pile; (d) $C_{2}$ pile.

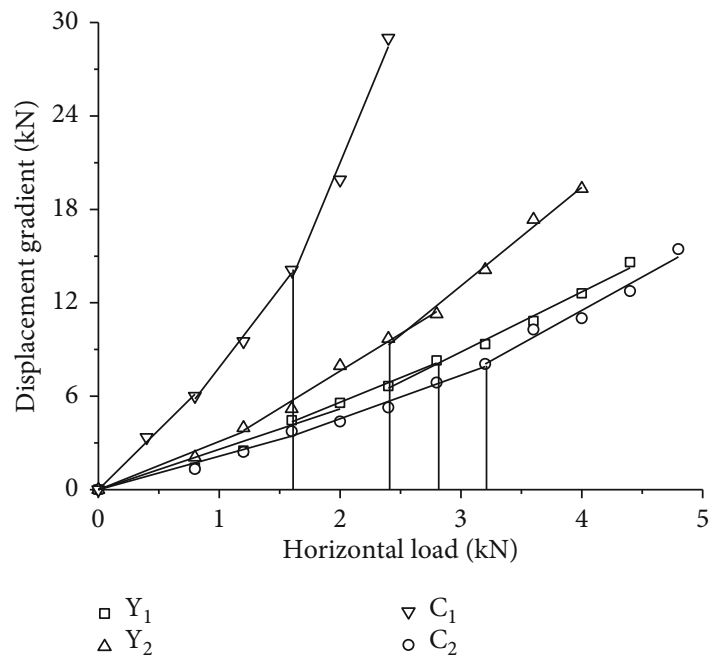

Figure 10: Horizontal load versus displacement gradient $\left(H_{0}-\Delta X_{0} / \Delta H_{0}\right)$.

the horizontal critical load $\left(H_{\mathrm{cr}}\right)$, ultimate horizontal load $\left(H_{u}\right)$, and corresponding displacements are obtained (Table 7); conclusions can be drawn:

(1) The horizontal ultimate bearing capacity for the convex direction of a $Y_{1}$ pile is larger than that in the concave direction of a $Y_{2}$ pile, by about 1.17 times, and for critical load, by about 1.33 times. It can be concluded that the horizontal bearing capacity of a Y-shaped pile has directionality

(2) The ultimate horizontal load of $Y_{1}$ and $Y_{2}$ piles is 1.75 and 1.5 times that of a $C_{1}$ pile (with the same cross-sectional area as the $\mathrm{Y}$-shaped pile), respectively, so changing a circular cross-section into a Y-shape can improve the horizontal bearing capacity in a particular direction for the same amount of concrete

(3) The ultimate horizontal load of $Y_{1}$ and $Y_{2}$ piles is 0.875 and 0.75 times that of a $C_{2}$ pile (with the same perimeter as the Y-shaped pile), respectively, so a Yshaped pile cannot give full play to the advantage of the larger side area for horizontal bearing capacity. Furthermore, a circular pile has no directionality and shows a better horizontal bearing behaviour than the equivalent Y-shaped pile; however, the ultimate horizontal load per unit amount of concrete of $Y_{1}$ and $Y_{2}$ piles is 2.14 and 1.83 times that of a $C_{2}$ pile, respectively, so the horizontal bearing effectiveness of the same amount of concrete in a Y-shaped pile is higher than that of a circular pile 
TABLE 7: Results of horizontal model tests.

\begin{tabular}{|c|c|c|c|c|}
\hline \multirow{2}{*}{ Items } & \multicolumn{4}{|c|}{ Values } \\
\hline & $Y_{1}$ pile & $Y_{2}$ pile & $C_{1}$ pile & $C_{2}$ pile \\
\hline Critical load $H_{\mathrm{cr}}(\mathrm{kN})$ & 1.6 & 1.2 & 0.8 & 1.6 \\
\hline Displacement $X_{\mathrm{cr}}(\mathrm{mm})$ & 3.90 & 3.26 & 3.74 & 3.53 \\
\hline Ultimate load $H_{u}(\mathrm{kN})$ & 2.8 & 2.4 & 1.6 & 3.2 \\
\hline Displacement $X_{u}(\mathrm{~mm})$ & 12.11 & 12.40 & 13.19 & 13.37 \\
\hline Ultimate load per concrete volume $\left(\mathrm{kN} / \mathrm{m}^{3}\right)$ & 280.4 & 240.4 & 160.3 & 131.3 \\
\hline
\end{tabular}

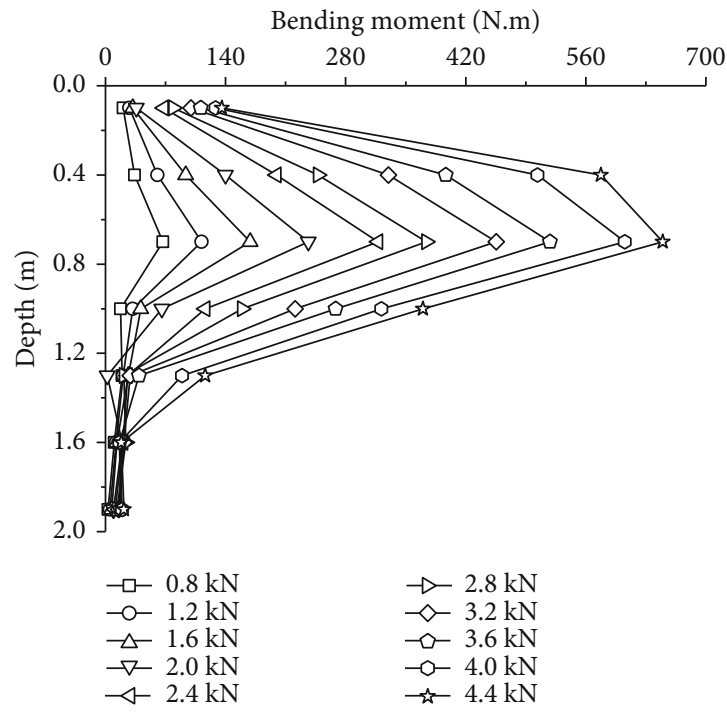

(a)

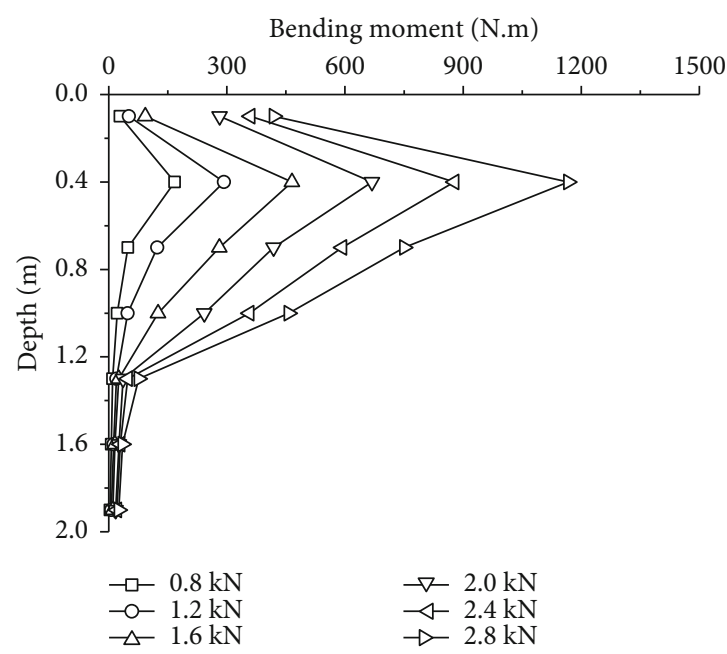

(c)

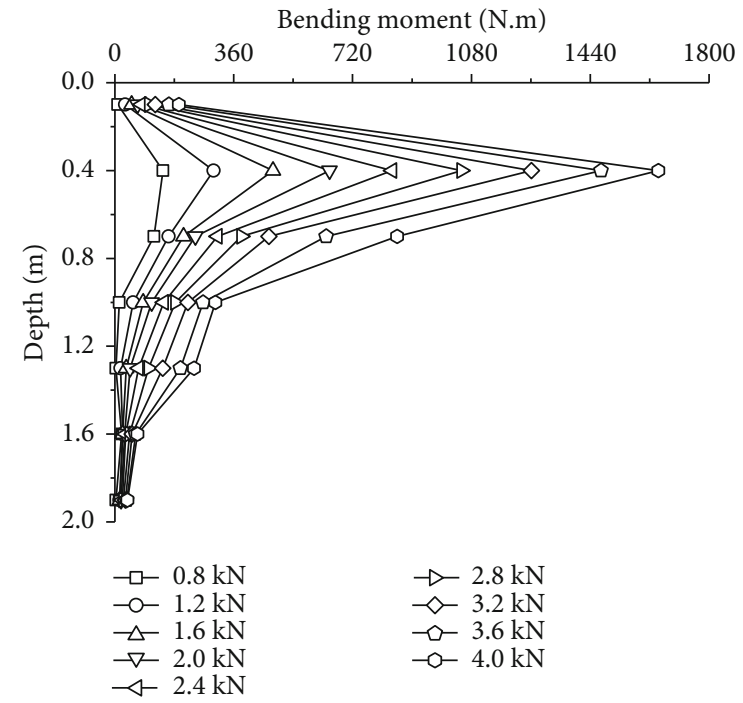

(b)

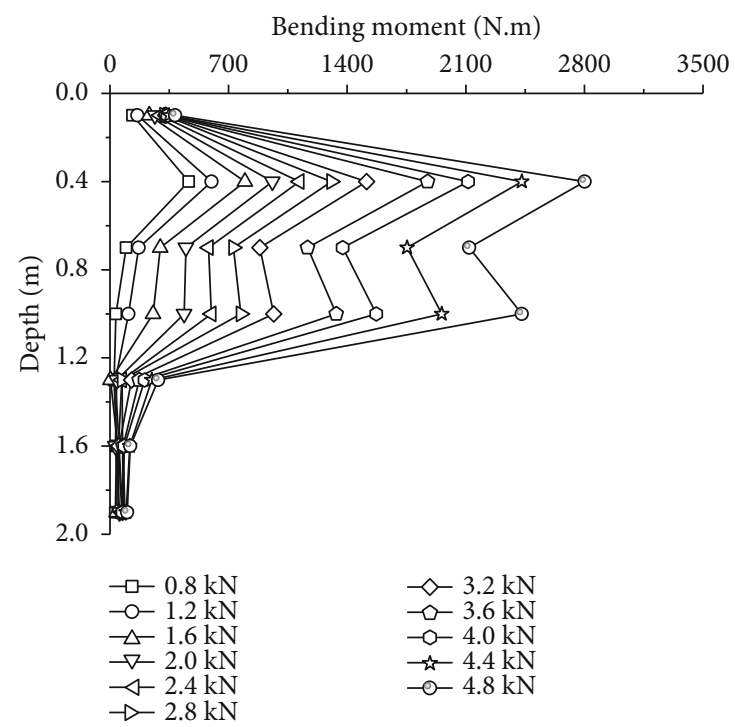

(d)

Figure 11: Bending moment along the pile: (a) $Y_{1}$ pile; (b) $Y_{2}$ pile; (c) $C_{1}$ pile; (d) $C_{2}$ pile.

3.6.2. Bending Moment. Formula (2) gives the bending moment along a pile is as follows [22]:

$$
M=E I \frac{\varepsilon_{c}+\varepsilon_{t}}{d},
$$

where $M$ is the bending moment on a given section, $\varepsilon_{c}$ is the compressive strain, $\varepsilon_{t}$ is the tensile strain, $E I$ is the bending stiffness, and $d$ is the distance between two given points.

First, the compressive and tensile strain of each monitoring section is measured, and then, the bending moment is 


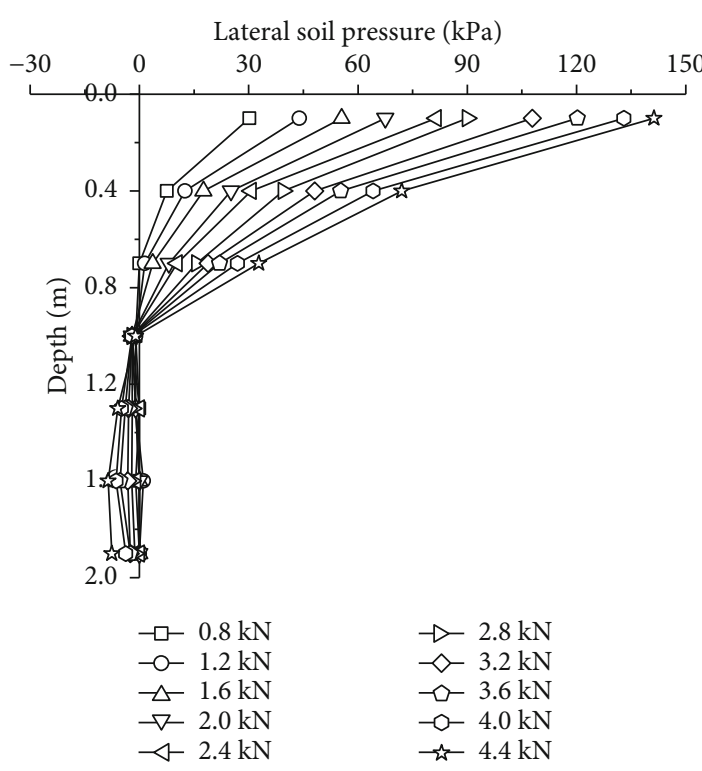

(a)

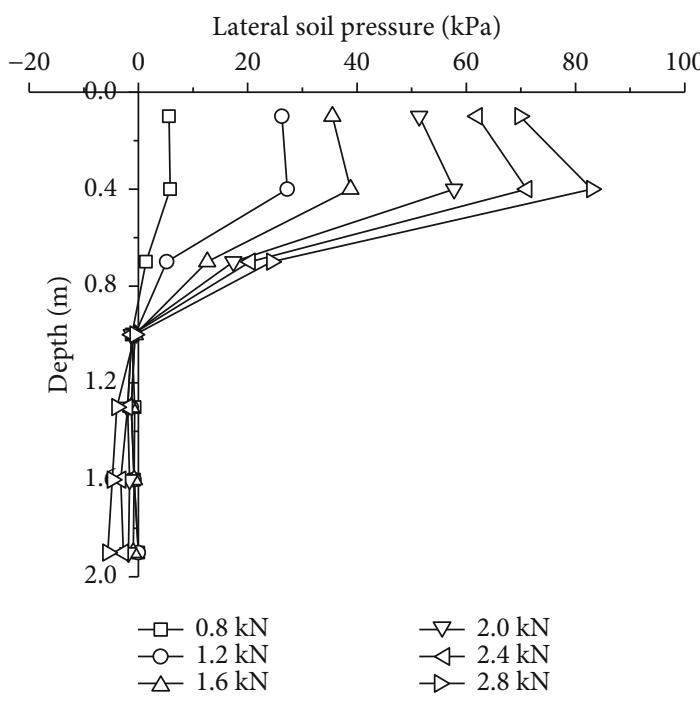

(c)

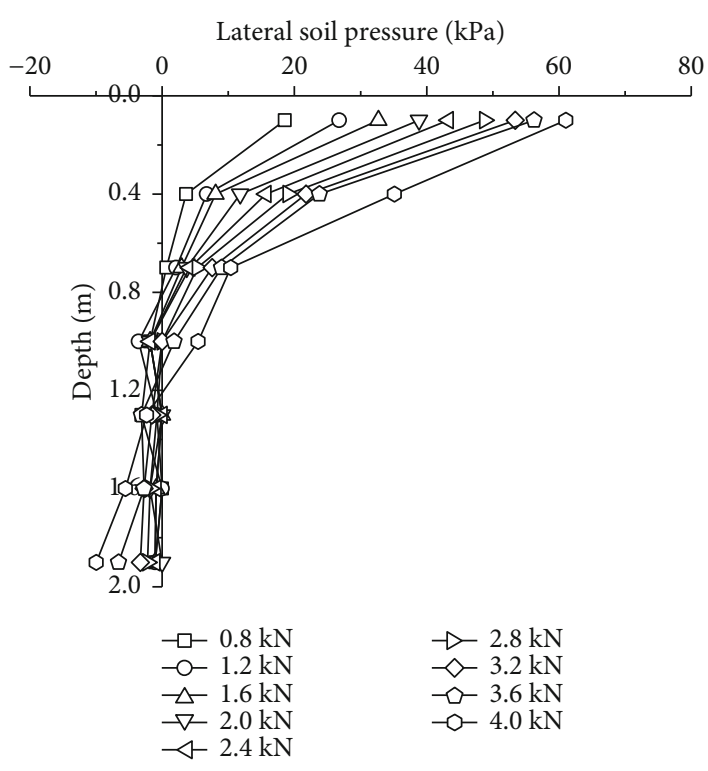

(b)

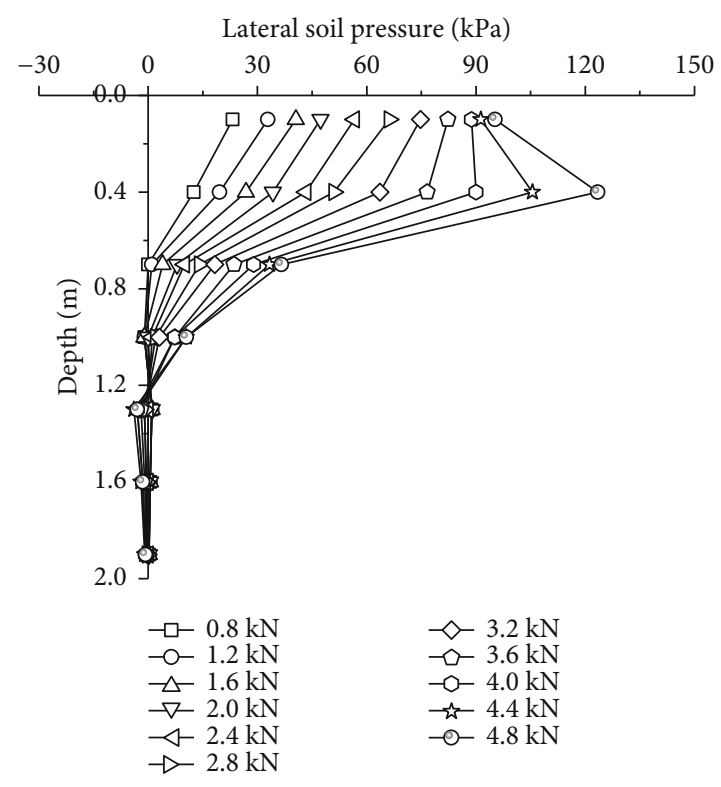

(d)

Figure 12: Lateral soil pressure along the pile: (a) $Y_{1}$ pile; (b) $Y_{2}$ pile; (c) $C_{1}$ pile; (d) $C_{2}$ pile.

calculated using formula (2). Bending moment distributions for the four model piles are shown in Figure 11.

Figure 11 shows that the bending moment of four model piles first increases, then decreases along with the pile where the moment increases with increasing load. The rate of increase of moment is small until the applied load exceeds the ultimate bearing capacity, when, the rate of increase becomes rapid, and the piles begin to crack.

The position of moment maximum for four piles is the same for each loading process. The positions of maximum moment for the $Y_{1}$ pile, $Y_{2}$ pile, $C_{1}$ pile, and $C_{2}$ pile are about $0.7 \mathrm{~m}, 0.4 \mathrm{~m}, 0.4 \mathrm{~m}$, and 0.4 to $1.0 \mathrm{~m}$ depth from the pile head, respectively.
All four piles were broken in these horizontal tests, so the model piles were excavated after testing. The crack position of the four piles is different: cracking occurred at around $0.56 \mathrm{~m}$ depth for the $C_{1}$ pile, about seven times its diameter; at around $0.88 \mathrm{~m}$ depth for a $C_{2}$ pile, again, about seven times its diameter: the crack positions on the two Y-shaped piles are at $0.48 \mathrm{~m}$ ( $Y_{1}$ pile, convex loading direction) and $0.69 \mathrm{~m}$ depth ( $Y_{2}$ pile, concave loading direction), depths of about four times and five times its circumcircle diameter, respectively. Crack positions for the different loading directions of Y-shaped piles are different: a comparison between circular piles and Y-shaped piles shows that crack depth for a Yshaped pile is less than that for a circular pile. The reinforced 
depth from pile head should be more than 10 times the diameter for a Y-shaped pile while 14 times the diameter for a circular pile.

Figures 12(a) and 12(b) show that the bending moment on a $Y_{1}$ pile is $374.2 \mathrm{Nm}$ at ultimate load $(2.8 \mathrm{kN})$, while the bending moment on a $Y_{2}$ pile is $839.9 \mathrm{Nm}$ at ultimate load $(2.4 \mathrm{kN})$. The bending moment in the convex direction is significantly larger than that in the concave direction. The directionality of the horizontal bearing capacity for Y-shaped pile has thus been demonstrated once again.

3.6.3. Lateral Soil Pressure Distribution. The lateral soil pressure along each pile is measured by soil pressure cells at each load. Figure 12 shows the lateral soil pressure distributions along with the four model piles. Figures 12(a) and 12(b) show that the lateral soil pressure distribution along the two Yshaped piles is similar: the upper is larger, the lower is smaller, and the maximum is seen at the pile head. An inflection point occurs at $1 \mathrm{~m}$ depth, the direction of soil pressure cells below $1 \mathrm{~m}$ depth is opposite those above $1 \mathrm{~m}$ depth. On the whole, the lateral soil pressure along a $Y_{1}$ pile is larger than that along a $Y_{2}$ pile, and it can be seen that the lateral soil pressure distribution also exhibits directionality. Figures $12(\mathrm{c})$ and $12(\mathrm{~d})$ show that the lateral soil pressure distribution along with $C_{1}$ and $C_{2}$ piles is similar, the upper reaches are larger, and the lower is smaller. The inflection points on $\mathrm{C}_{1}$ and $\mathrm{C}_{2}$ piles occur at $1 \mathrm{~m}$ and $1.2 \mathrm{~m}$ depths, respectively. The lateral soil pressure along with a $C_{2}$ pile is greater than that on a $Y_{1}$ pile, so the greater side area of the circular pile is better at mobilising the wider range of soil around the pile to bear greater horizontal load.

Lateral soil pressure distributions along with Y-shaped and circular piles are similar; the depths to the inflection points are similar, and as the horizontal load increases, the upper soil around the pile begins to bear load, the lateral soil pressure increases, and then transfer to a deeper and wider zone in the soil such that, over time, and under load, the soil zone of influence depth is about 10 times the pile diameter as maximum horizontal load.

\section{Conclusions}

A series of model tests under compressive and horizontal load in saturated sand was carried out on a Y-shaped pile, a $C_{1}$ circular pile (with the same cross-sectional area as the Y-shaped pile), and a $C_{2}$ circular pile (with the same perimeter as the Y-shaped pile); sand was pluviated into a tank containing the model piles; then, this was filled with water until complete soil saturation was achieved. Comparative analysis of data from load tests on Y-shaped piles and circular piles was undertaken, and the following conclusions were drawn:

(1) The compressive bearing capacity of a Y-shaped pile is 1.29 times that of an equivalent $C_{1}$ pile, but its perimeter is 1.56 times that of the $C_{1}$ pile, so the bearing capacity of $\mathrm{Y}$-shaped pile in saturated sand does not increase in proportion thereto and its shaft resistance is weakened to some extent. The compressive bearing capacity of a $C_{2}$ pile is 1.13 times that of the equivalent $\mathrm{Y}$-shaped pile because of its larger crosssectional area and greater tip resistance, while the bearing capacity per unit amount of concrete of a Y-shaped pile is 2.16 times that of a $C_{2}$ pile, so Yshaped section piles can improve the compressive bearing capacity for the same amount of concrete. The side friction sharing ratio can be improved in saturated sand when the circular section is swapped for the equivalent $\mathrm{Y}$-shaped section but is slightly less than that of $\mathrm{a}_{2}$ pile although both have the same cross-sectional area

(2) The bearing capacity ratio (in model tests) for Yshaped and circular piles is a little smaller than that measured in field tests under compressive loading

(3) The horizontal bearing capacity of a $Y_{1}$ pile in the convex loading direction is greater than that of a $Y_{2}$ pile in the concave loading direction: the directionality of Y-shaped piles is thus demonstrated. The ultimate horizontal load of $Y_{1}$ and $Y_{2}$ piles is 1.75 and 1.5 times that of a $C_{1}$ pile, respectively. Changing a circular cross-section pile for an equivalent $\mathrm{Y}$ shaped section can improve the horizontal bearing capacity for the same amount concrete. The ultimate horizontal loads of $Y_{1}$ and $Y_{2}$ piles are 0.875 and 0.75 times that of a $C_{2}$ pile, respectively; so a Y-shaped pile cannot give full play to the advantage of a larger side area with regard to horizontal bearing capacity. Furthermore, a circular pile can bear any direction of horizontal load and has no directionality: this is impossible for a Y-shaped pile

(4) The ultimate horizontal load per unit amount of concrete for a Y-shaped pile is significantly higher than that of a $C_{2}$ pile, so Y-shaped piles can achieve a higher horizontal bearing capacity in a particular direction with less concrete. The crack position sits at a position some seven times its diameter down both the $C_{1}$ and $C_{2}$ piles, while cracking was seen at depths of four and five times the pile diameter for $Y_{1}$ and $Y_{2}$ piles, respectively. The crack depth in $Y$ shaped piles is less than that in circular piles, so it can be concluded that Y-shaped piles with less concrete cause the broken section depth to decrease. The reinforced depth should be more 10 times the circumscribed diameter for a Y-shaped pile, and 14 times the diameter for a circular pile

\section{Data Availability}

The data used to support the findings of this study are included within the article.

\section{Conflicts of Interest}

The authors declare that they have no conflicts of interest regarding the publication of this paper. 


\section{Acknowledgments}

The inspirational collaborative support received from the Centre for Geomechanics \& Railway Engineering, University of Wollongong, Australia has been instrumental in the research progress reported in this paper. This work was supported by the National Natural Science Foundation of China (No. U1810203).

\section{References}

[1] J. Yang, L. G. Tham, P. K. Lee, and F. Yu, "Observed performance of long steel h-piles jacked into sandy soils," Journal of Geotechnical and Geoenvironmental Engineering, vol. 132, no. 1, pp. 24-35, 2006.

[2] M. H. E. Naggar and M. Sakr, "Evaluation of axial performance of tapered piles from centrifuge tests," Canadian Geotechnical Journal, vol. 37, no. 6, pp. 1295-1308, 2000.

[3] J. He, J. Liu, Q. G. Yang, and Y. P. Wu, "Load transfer behaviour of a tapered rigid pile," Geotechnique, vol. 62, no. 7, pp. 649-652, 2012.

[4] E. Dickin and C. F. Leung, "Performance of piles with enlarged bases subject to uplift forces," Canadian Geotechnical Journal, vol. 27, no. 5, pp. 546-556, 1990.

[5] T. Honda, Y. Hirai, and E. Sato, "Uplift capacity of belled and multi-belled piles in dense sand," Soils and Foundations, vol. 51, no. 3, pp. 483-496, 2011.

[6] M. Y. Fattah and W. H. S. Al-Soudani, "Bearing capacity of closed and open ended pipe piles installed in loose sand with emphasis on soil plug," Indian journal of geo-marine sciences, vol. 45, no. 5, pp. 703-724, 2016.

[7] M. Y. Fattah, S. A. al-Haddad, and M. K. Hameedi, "Load carrying capacity of rectangular foundation on geogrid reinforced sloped sandy soil," IOP Conference Series: Materials Science and Engineering, vol. 737, p. 12094, 2020.

[8] M. Y. Fattah, B. S. Zabar, and F. S. Mustafa, "Effect of saturation on response of a single pile embedded in saturated sandy soil to vertical vibration," European Journal of Environmental and Civil Engineering, vol. 24, no. 3, pp. 381-400, 2020.

[9] L. W. Ren, W. D. Guo, and Y. B. Deng, "Analysis of vertically loaded jet-grout-pile-strengthened piles of expanded crosssection," Proceedings of the Institution of Civil Engineers - Geotechnical Engineering, vol. 171, no. 3, pp. 252-266, 2018.

[10] Z. Q. Wang, H. L. Liu, M. X. Zhang, J. Yuan, and J. Yong, "Full scale model tests on vertical bearing characteristics of cast-inplace X-section pile," Chinese Journal of Geotechnical Engineering, vol. 36, no. 2, pp. 903-907, 2010.

[11] Y. R. Lv, H. L. Liu, X. M. Ding, and G. Q. Kong, "Field tests on bearing characteristics of $\mathrm{x}$-section pile composite foundation," Journal of Performance of Constructed Facilities, vol. 26, no. 2, pp. 180-189, 2012.

[12] G. Q. Kong, H. Zhou, X. M. Ding, and Z. H. Cao, "Measuring effects of X-section pile installation in soft clay," Proceedings of the Institution of Civil Engineers-Geotechnical Engineering, vol. 168, no. 4, pp. 296-305, 2015.

[13] H. L. Liu, H. Zhou, and G. Q. Kong, "XCC pile installation effect in soft soil ground: a simplified analytical model," Computers and Geotechnics, vol. 62, pp. 268-282, 2014.

[14] Y. R. Lv, H. L. Liu, C. W. W. Ng, X. M. Ding, and A. Gunawan, "Three-dimensional numerical analysis of the stress transfer mechanism of xcc piled raft foundation," Computers and Geotechnics, vol. 55, no. 55, pp. 365-377, 2014.

[15] J. H. Lu and X. M. Lu, "Field test and study of Y-shaped pile, an unusual type of driven cast-in-situ concrete pile," Journal of Zhejiang Water Conservancy and Hydropower College, vol. 14, no. 4, pp. 40-42, 2002.

[16] L. X. Xu, S. H. Yang, and B. Duan, "Field tests on Y-shaped vibro piles to improve soft clay ground under the expressways," Chinese Journal of Geotechnical Engineering, vol. 29, no. 1, pp. 120-124, 2007.

[17] X. Q. Wang, Y. H. Chen, F. Lin, X. Y. Lu, and T. Zhang, "Evaluation of ultimate bearing capacity of Y-shaped vibro-pile," Journal of Central South University of Technology, vol. 15, no. S2, pp. 186-194, 2008.

[18] X. Q. Wang, Y. H. Chen, and H. L. Liu, "In-situ study on load transfer mechanism of y-shaped vibro-pile," Chinese Journal of Rock Mechanics and Engineering, vol. 27, no. 3, pp. 615-623, 2008.

[19] Y. H. Chen, X. Q. Wang, and H. L. Liu, "Research on abnormity characteristic of Y-shaped tube-sinking cast-in-situ pile in highway soft ground," China Journal of Highway and Transport, vol. 21, no. 5, pp. 9-25, 2008.

[20] R. P. Chen, Z. Z. Xu, Y. M. Chen, D. S. Ling, and B. Zhu, "Field tests on pile-supported embankments over soft ground," Journal of Geotechnical and Geoenvironmental Engineering, vol. 136, no. 6, pp. 777-785, 2009.

[21] L. W. Ren, W. D. Guo, and Q. W. Yang, “Analysis on bearing performance of Y-shaped piles under compressive and tensile loading," Proceedings of the Institution of Civil Engineers Geotechnical Engineering, vol. 173, no. 1, pp. 58-69, 2020.

[22] J. He, Research on the behavior of Y-shaped sinking pipe pile under lateral loads, [M.S. dissertation], Hohai University, Nanjing, China, 2007.

[23] S. Chian, M. Stringer, and S. Madabhushi, "Use of automatic sand pourers for loose sand models," in Proceedings of VII international conference on physical model in geotechnics (ICPMG 2010), Zurich, Taylor \& Francis, 2010.

[24] Y. Zhao, K. Gafar, M. Elshafie, A. Deeks, J. Knappett, and S. Madabhushi, "Calibration and use of a new automatic sand pourer," in Physical Modelling in Geotechnics, pp. 265-270, taylor \& francis group, 2006.

[25] The Ministry of Water Resources of the People's Republic of China, "Standard GB (GB/T 50123-2019) for Geotechnical Test Methods," in Issued on June 10, 2019 and Implemented on October 1, 2019, China Planning Press, 2019.

[26] GB50007-2011, Code for Design of Building Foundation, Ministry of Housing and Urban-Rural Development, Beijing, China, 2011.

[27] B. Bienen, J. Dührkop, J. Grabe, M. F. Randolph, and D. J. White, "Response of piles with wings to monotonic and cyclic lateral loading in sand," Journal of Geotechnical and Geoenvironmental Engineering, vol. 138, no. 3, pp. 364-375, 2011.

[28] C. LeBlanc, G. Houlsby, and B. Byrne, "Response of stiff piles in sand to long-term cyclic lateral loading," Geotechnique, vol. 60, no. 2, pp. 79-90, 2010. 